\title{
BURN VICTIMS AND SKIN DONATIONS: A LEGAL PERSPECTIVE
}

\author{
Magda Slabbert \\ BA (Hons) HED BPROC LLB LLD \\ Professor, Department of Jurisprudence \\ University of South Africa, Pretoria (UNISA) \\ Bonnie Venter \\ LLB LLM \\ PhD Candidate, Centre for Health, Law, and \\ Society, University of Bristol Law School \\ University of Bristol, England
}

\section{SUMMARY}

This article highlights the need for skin donations to treat burn wounds. South Africa has an exceptionally high number of burn wound victims per annum. The ideal way to treat burn wounds is to transplant skin from another part of the patient's body to the affected areas (autografts). Unfortunately, this is not always possible or feasible and in those cases skin from cadavers (allografts) should be used, but this can only be done if the deceased has indicated a wish during his or her lifetime that tissue be donated for transplantation use after death. If the deceased has not indicated his or her wish to be a tissue donor, family members could be asked to consent to a donation. The article looks at the legal requirements in South Africa for a valid skin donation as well as the requirements should skin be imported owing to a lack of enough tissue donors in the country. This position is contrasted to the position in the United Kingdom with a view to establishing whether South Africa can learn from another jurisdiction concerning the procurement of skin for transplantation. The possible reasons that people do not donate skin are also touched upon.

"[O]ne of the hardest things about getting sick, really sick, is that you are separated from the people you love. Even when families are dedicated to the patient, illness separates the well from the sick. The sick suffer alone, they undergo procedures and surgeries alone, and in the end, they die alone. Transplant is different. Transplant is all about having someone else join you in your illness. It may be in the form of an organ from a recently deceased donor, a selfless gift given by someone who has never met you, or a kidney or liver from a relative, friend or acquaintance. In every case, someone is saying in effect, let me join you in your recovery, your suffering, your fear of the 
unknown, your desire to become healthy, to get your life back. Let me bear some of your risk with you."1

\section{$1 \quad$ INTRODUCTION}

According to the World Health Organisation (WHO), nearly 180000 people die annually from burn wounds, making this a global public health problem, with the highest number of deaths being in Africa and South-East Asia. ${ }^{2}$ Non-fatal burns are a leading cause of morbidity, including prolonged hospitalisation, disfigurement and, in some cases, even disability that results in social rejection. ${ }^{3}$ In South Africa, nearly 1.6 million people suffer from burn wounds annually, with approximately 268 severe cases being reported every month. ${ }^{4}$ An estimated R364 million is spent annually for care of burns from kerosene (paraffin) cook stove incidents. ${ }^{5}$ The socio-economic effects of these incidents include loss of income and prolonged care, as well as the emotional trauma associated with burn wounds.

Between April 2014 and March 2015, 3206 burn patients were treated by a burn care unit at one private hospital group in South Africa. Of these, 1859 were male burn victims, suggesting that many of these injuries are work-related. ${ }^{6}$ Children are also hugely vulnerable as the South Africa has a rate of 2.8 burn-related deaths per 100000 children, which is more than five times higher than other middle-income countries, which average 0.5 burnrelated deaths per 100000 children. $^{7}$ Infants and small children have a larger skin surface area because of their larger head circumference and shorter legs in proportion to their body size, causing increased evaporative losses and decreased body temperature compared to adults. Infants also have a thinner dermis causing deeper burn wounds. ${ }^{8}$ According to Martinez, death from burn wounds occurs mainly because there are no effective, affordable and synthetic treatment options available. ${ }^{9}$ The best solution for

Mezrich How Death Becomes Life (2019) 19-20. The sick in this instance could be the burn victim and the donation of skin could be the joining in recovery.

2 Anon "Burns" 6 March 2018 https://www.who.int/news-room/fact-sheets/detail/burns (accessed 2019-02-26).

3 lbid.

4 Ngobeni "Shortage of Skin for Burn Victims" 2018 Rekord Centurion https://rekordcenturion.co.za/151245/shortage-of-skin-for-burn-victims/ (accessed 2019-0301). See also Allorto, Wall and Clarke "Quantifying Capacity for Burn Care in South Africa" 2018 Burns Open 188-192 for burn wound statistics per province in SA.

5 Anon https://www.who.int/news-room/fact-sheets/detail/burns. See also Rode, Berg and Rodgers "Burn Care in South Africa" 2011 24(1) Annals of Burns and Fire Disasters 7-8.

6 Nicholson, Swinney, Wilson and Saville "Netcare Burn Statistics 2014/2015: An EyeOpener" http://www.netcare.co.za/News-Hub/Articles/Articleld/248/netcare-burns-stistics-20 (accessed 2019-02-26).

7 Wesson, Bachani, Mtambeka, Millar, Hyder and Van As "Pediatric Burn Injuries in South Africa: A 15-Year Analysis of Hospital Data" 201344 Injury: International Journal of the Care of the Injured 1477-1482. See also Burn Care Trust https://www.burncare.co.za/ (accessed 2019-02-26).

8 Moss "Treatment of Burn Patient in Primary Care" 2010 23(11) Advances in Skin \& Wound Care 517-524.

9 Dr Roux Martinez, head of the only specialized pediatric burn unit in Africa, as quoted in Ngobeni "Shortage of Skin for Burn Victims" 2018 Rekord Centurion 
this problem is cadaveric human skin. The statistics of children dying from burn wounds reflect numbers that are staggering and are a good indication of the number of burn injuries suffered by children in the country. Every citizen could make a difference to these statistics by deciding in favour of skin donation after their own death or the death of a loved one. ${ }^{10}$

A burn wound is the destruction of skin that meets flames, hot fluids, electricity or radiation. The severity of the burn injury is determined by the amount of surface area of the skin that is damaged and the depth of the tissue that is involved. ${ }^{11}$ Excessive skin injuries do not have the capacity for healing on their own and require surgery. When possible and available, skin is taken from unburnt parts of the patient's own body and transplanted onto the injured parts. This is known as an autograft. Often there is no unburnt skin available for transplantation and the need then arises for donated skin. The process of transplanting donated skin from a donor onto a burn victim is known as an allograft.

The biggest problem with treating burn wounds is the unavailability of donor skin. Donor skin from cadavers "is recognized as the gold standard for temporary cover following early excision when insufficient autograft is available". ${ }^{12}$ Skin protects the body against physical or biological trauma. When donor skin is used to cover burn wounds, it is a temporary measure and it helps with the heat and fluid loss as well as protecting the burn victim against infections and immense pain. ${ }^{13}$ Because donated skin functions as a temporary measure, there is no need for tissue typing. As alluded to by specialists in the field, "the cadaveric skin promotes epithelialisation, suppresses infection, prepares the wound bed for definitive closure, provides a dermal template for epithelial grafts and prevents desiccation of tissue". ${ }^{14}$ Before 2016, South Africa did not have an official skin donation programme. ${ }^{15}$ Specialists used skin procured on their orders from dead donors but there was no official policy regulating the procurement of skin or the transplantation thereof. If no human skin was available, the skin of pigs was used as an alternative. This is called xenotransplantation and is not the

https://rekordcenturion.co.za/151245/shortage-of-skin-for-burn-victims/ (accessed 2019-0301).

10 Ngobeni 2018 Rekord Centurion.

11 Burn Care Trust "A National Skin Bank for South Africa" https://www.burncare.co.za/ national-skin-bank-south-africa/ (accessed 2019-02-26).

12 Ibid.

13 Most burn wounds are painful because the sensory nerve endings in the skin remain intact but become exposed because of the loss of the epidermis. See Moss 2010 Advances in Skin \& Wound Care 517-524.

14 Rhode, Rogers, Adams, Kleintjes, Whitelock-Jones, Muganza and Allorto "The Dilemma of Treating Major Burns in South Africa" 2013 SAMJ 2.

15 The first allograft skin bank was established at Bewerwick, Holland, in 1952. A skin bank was also introduced in India in 2000. See Gore "Cadaver Skin Donation and Skin Bank" 2017 Indian Journal of Burns 3-5. See also Rhode et al 2013 SAMJ 1-4, in which the following is stated: "To serve the greater population of burn victims, every effort should be made to establish a skin bank for universal use, rather than channeling scarce financial resources into procedures that have a very limited role in SA." 
ideal situation and raises many legal and ethical questions as cross-species infections could manifest. ${ }^{16}$

The purpose of this article is to provide an overview of how human skin donations are regulated in South Africa. The article commences with the legal and regulatory framework relating to skin donations in South Africa. This is followed by a brief comparative discussion on the legal position in the United Kingdom (England and Wales). In order to provide further context to this discussion, the article then posits the possible reasons for the lack of donated skin. The article concludes by considering the legality of importing cadaver skin as a possible solution for the shortage of donated skin. The focus is only on allografts, as the only option to treat more severe burn wound cases is to use donated cadaver skin.

\section{THE LAW AND SKIN DONATIONS IN SOUTH AFRICA}

\section{The Constitution of the Republic of South Africa}

Section 2 of the Constitution of the Republic of South Africa, 1996 (the Constitution) states: "The Constitution is the supreme law of the Republic; law or conduct inconsistent with it is invalid, and the obligations imposed by it must be fulfilled." Section 27(1) of the Constitution stipulates that everyone has the right to have access to health care services. Although this sounds plausible, it should be noted that the above-mentioned right to access health care is internally limited by section $27(2)$, which stipulates that the State must take reasonable legislative and other measures within its available resources to achieve the progressive realisation of this right. ${ }^{17}$

The constitutional validity of the statutory framework guiding organ and tissue donations has not been tested by South African courts. It is often misconstrued that the case of Soobramoney $v$ Minister of Health (KwaZuluNatal) ${ }^{18}$ might have an influence in this field but the legal issues in this case were specifically about the provision of haemodialysis as an emergency health care measure. The legal measures guiding the transplant process have not been evaluated. It could therefore be accepted that the donation of organs and tissue, as well as subsequent transplantation thereof, is constitutionally acceptable by virtue of the fact that no part of the National Health Act $^{19}(\mathrm{NHA})$ or accompanying regulations has been declared unconstitutional.

16 See Slabbert "Xenotransplantation" 2015 36(3) Obiter 725-737.

17 For a constitutional perspective on organ and tissue donations and transplantation, see Venter "A Selection of Constitutional Perspectives on Human Kidney Sales" (unpublished LLM dissertation, University of South Africa) 2012; Labuschagne "An Analysis of Organ Transplantation in South Africa With Specific Reference to Organ Procurement" (unpublished LLM dissertation, University of Pretoria) 2013.

181997 (1) SA 765 (CC).

1961 of 2003. 


\section{The National Health Act 61 of 2003}

The NHA repealed the Human Tissue Act 65 of $1983 .{ }^{20}$ Chapter 8 of the NHA regulates deceased and living tissue donation as well as subsequent transplantation. ${ }^{21}$ As indicated earlier, the focus of this article is only on the use of human skin from deceased donors (cadavers). Section 1 of the Act defines tissue as "human tissue and includes flesh, bone, a gland, an organ, skin (author's own emphasis), bone marrow or body fluid, but excludes blood or a gamete". Skin is thus regarded as tissue according to the NHA.

Section 62 of the NHA mandates how a person should indicate their decision to become an organ or tissue donor after their death. According to section $62(1)(a)$ of the NHA, a person who is competent to make a will (16 years or older) may in a will, ${ }^{22}$ or a document signed by him or her and at least two competent witnesses (14 years or older); 23 or in an oral statement made in the presence of at least two competent witnesses, ${ }^{24}$ donate his or her body or any specified tissue (skin) thereof to be used after his or her death. This section, however, raises numerous practical difficulties, which are discussed below.

First, section $62(1)(a)(i)$ specifies that a living competent person may dispose of his or her tissue in a will. However, after the death of a person, a will has to be validated by the Master of the High Court. ${ }^{25}$ This process could take several days or even months. Ideally, skin should be procured within six hours after death, but this is merely a guideline for best practice, as sometimes skin is procured a few days after death. ${ }^{26}$ Thus, to record a wish that you want to be a skin donor after your death in a will seems futile, except if it is regarded as guidance to family members, who have knowledge of the contents of the will, and who will have to make a decision concerning a skin donation. ${ }^{27}$

Secondly, section $62(1)(a)(i i)$ relates to the fact that a person can donate their tissue by signing a document in the presence of two competent witnesses, this section could be interpreted in various ways. Before discussing these different ways, it is interesting to note that this section of the Act is only supposed to be applicable to deceased donation. Yet, this is

20 In 2012, Chapter 8 of the NHA came into effect, and repealed the Human Tissue Act 65 of 1983; see Proc 11 in GG 35081 of 2012-02-27.

21 See also Slabbert "The Law as an Obstacle in Solid Organ Donations and Transplantations" 2018 THRHR 70.

$22 \mathrm{~S} 62(1)(a)(\mathrm{i})$ of the NHA.

${ }^{23} \mathrm{~S} 62(1)(a)(\mathrm{ii})$ of the NHA.

$24 \mathrm{~S} 62(10)(a)$ (iii) of the NHA.

25 For another perspective, see Slabbert "Burial or Cremation: Who Decides?" 2016 De Jure 230-241, at 232-235, where the deceased's wishes in a will is discussed.

26 Skin Donation "Facts" http://www.skindonation.in/facts.html (accessed 2019-02-26). The harvesting process takes about $30-45$ minutes. A battery-operated instrument is used and only the uppermost layer is shaved off. There is no bleeding and bandages are put over the parts where skin was taken. There is no disfigurement of the body.

27 South Africa follows a system of opting-in, meaning individuals or their family members must consent to a tissue donation. If there is no explicit consent, no tissue will be taken for transplantation purposes. Donations are done altruistically. 
also the process used for living tissue (bone) donations. Within the clinical environment, a transplant coordinator will ask a person whether they are willing to act as a living bone donor by providing them with the option to donate the femoral head when removed from their body during hipreplacement surgery. In this case, the donor's consent is recorded when the donor signs a donor consent form in the presence of two witnesses. ${ }^{28}$

When this process is followed in the case of a deceased donor, such a signed document could be compared to a living will, ${ }^{29}$ which has no legal status in South Africa. ${ }^{30}$ The document thus only serves as a directive to the family of the deceased when they are asked to consent to the tissue (skin) donation from the deceased. ${ }^{31}$ If it is assumed that this part of the Act refers to the registration process of becoming a tissue donor while alive, it seems irrelevant as registration on the Organ Donor Foundation's (ODF) website 32 can be done online without following the same formalities. The online registration does not require the presence of two witnesses - neither their details nor signatures are captured. It is in any event best practice in the clinical environment for a transplant coordinator always to ask the family of the deceased for consent to a donation. For this to occur, the hospital has to refer the death to a transplant coordinator. ${ }^{33}$ No coordinator will act and accept a donation by virtue of an indication that the deceased made a choice to be a tissue donor while still alive - for example, by having a written signed document, a sticker on his or her driver's licence, or wearing a bracelet stating "tissue donor".

Thirdly, the stipulation in the Act that tissue can be donated in an oral statement in the presence of competent witnesses also raises practical concerns. For example, who will attest to such a statement? Who will do research to verify the validity of such a statement or where will the witnesses be found when one takes into consideration the time constraints associated with donations? Furthermore, this approach has not been followed in hospitals that perform transplantations. The relevance of this section might only be found if the family of the deceased consents to the donation based

28 S 55 of the NHA addresses the removal of tissue from a living person. This must be done with the written consent of the donor, granted in the prescribed manner, and in accordance with prescribed conditions. Neither the Act nor the Regulations clarify what these conditions are.

29 A living will is a declaration or an advance directive that represents a person's wishes. It is not a will in the testamentary sense of the word. There is in South Africa, at present, no law regarding the validity or enforceability of a living will; see South African Medical Association "Living Wills and Advance Directive" www.samedical.org>guidelines-with-regard-to-livingwills-2012.pdf (accessed 2020-01-25).

30 See Clarke $v$ Hurst 1992 (4) SA 630 (D). "There is in South Africa at present no law regarding the validity or enforceability of living wills": see South African Medical Association SAMA www.samedical.org>guidelines-with-regard-to-living-will-2012.pdf (accessed 201906-15).)

31 "A regular will is always respected, even if the next of kin do not like it"; see Van Diest, Lopes and Niesing "Cadaveric Tissue Donation: A Pathologist's Perspective" $2003 \mathrm{~J}$ Med Ethics 135-136.

32 Organ Donor Foundation www.odf.org.za.

33 There is no routine referral system in SA. See Slabbert and Venter "Routine Referrals: A Possible Solution for Transplantation Shortages" 2017 South African Journal of Bioethics \& Law 15-19. 
on the fact that the deceased made it known (orally) that he or she wanted to be a donor after death. It therefore seems that section 62(1) in the NHA serves no real purpose with regard to enhancing skin donations.

Within this context, it should be borne in mind that the legal and regulatory framework does not function in isolation but is implemented within a clinical environment. In this setting, the transplant coordinator is tasked with the responsibility of seeking consent from a relative of the deceased for a tissue (skin) donation. In this case, the relevant relative can in fact veto the decision that the deceased made while still alive. ${ }^{34}$ Family members may be influenced by a variety of factors, such as not knowing the deceased's wishes or fear of bodily disfigurement. ${ }^{35}$ Veatch feels strongly that family members should respect the wishes of the deceased if they are known. He asserts "the body is still the mortal remains of an individual and his or her wishes deserve respect". ${ }^{36} \mathrm{He}$ refers to the deontological theory of "duty", which, in the context of tissue donation, means we owe a duty to the dead, regardless of the consequences. In other words, the deceased's wishes should be honoured regardless of the family's own view on tissue (skin) donation. There must be respect for the autonomy of the deceased exercised before death to make a choice to donate human tissue (skin) or not. To this end, Veatch states, "the ethical principle of respect for autonomy is one of the most profound and widely affirmed deontological duties" ${ }^{37} \mathrm{He}$ concludes by saying that, in practice, the deceased's own wishes must prevail. Any indication that the deceased wanted to donate tissue (skin) should be enough to authorise tissue procurement even if the family objects. He argues that the procurement organisation ${ }^{38}$ has a moral duty - not just a right - to follow the deceased's wishes. ${ }^{39}$ If his argument could be followed in South African hospitals where donor referrals are made, it would make a huge difference to the number of tissue donations and would be more in line with respect for personal choices.

Section 62(2) of the NHA states: "[in] the absence of a donation under subsection (1)(a)", the family of the deceased, in a specific order, ${ }^{40}$ should be asked for consent for a donation. The Act is thus clear that the family should only be asked in the absence of a will, a signed document or an oral statement made by the deceased. Yet, as indicated above, good practice is always to ask the family for consent. If family members do not give consent or if there is a disagreement between them, the donation will not happen. ${ }^{41}$ If

34 Cay "Contemporary Issues in Law and Ethics: Exploring the Family Veto for Organ Donation" 2019 Journal of Perioperative Practice 1-7. See also Isdale and Savulescu "Families Shouldn't Be Allowed to Veto Organ Donation" (2016) http://bit.ly/2vO9DuD (accessed 2017-06-15).

35 Cay 2019 Journal of Perioperative Practice 1.

36 Veatch Transplantation Ethics (2000) 146.

37 Veatch Transplantation Ethics 147.

8 South Africa does not have a procurement agency functioning nationwide.

Veatch Transplantation Ethics 148.

40 The order in which persons should be asked for consent, according to s 62(2) of the NHA, is: spouse, partner, major child, parent, guardian, major brother or major sister.

41 See also Van Diest, Lopes and Niesing "Cadaveric Tissue Donation: A Pathologist's Perspective" 2003 J Med Ethics 135. 
consent for a skin donation is given in writing by the family of the deceased, the procurement of the skin takes place. It is usually done by a retrieval officer from an authorised tissue bank. ${ }^{42}$

According to section 54 of the NHA, the Minister of Health may designate an institution as an authorised institution, which may acquire and supply tissue (skin). Such an institution may receive payment in respect of the acquisition and supply of the tissue. However, the amounts may not exceed an amount that is reasonably required to cover the costs involved with the acquisition or supply of the tissue..$^{43} \mathrm{~A}$ tissue bank must therefore ideally be a non-profit company in terms of the Companies Act. ${ }^{44}$ To sell or trade in human tissue is an offence; 45 if convicted, a person could be given a fine or imprisonment for a period not exceeding five years, or both a fine and such imprisonment. ${ }^{46}$ Section $61(5)(a)$ of the NHA also states clearly that a person who charges a fee for human tissue shall be guilty of an offence and the same punishment as above is prescribed.

Skin is not an organ according to the NHA and it is not necessary to procure skin while the blood flow continues, albeit artificially as, for example, in the case of a brain-dead donor donating solid organs. Therefore, skin can be procured in a mortuary or a funeral home. Section 67 of the NHA prescribes that a medical practitioner in charge of a mortuary may, in writing and in the prescribed manner, authorise an authorised institution (tissue bank) to remove any specified tissue from a body before burial, on condition that permission has been given by the family for a donation to take place. At post-mortem examinations, donated tissue that is not relevant to the outcome of the post mortem may also be provided to an authorised institution at its request. ${ }^{47}$

Section 68 of the NHA authorises the Minister to make regulations in terms of the Act. This has been done and it is important to note that these regulations are as important as the Act itself, as they contain further detail regarding specific matters in Chapter 8 . Only those parts of the regulations applicable (or possibly applicable) to skin donations and transplantation are highlighted in the parts to follow. Different sets of regulations are discussed and this underscores the difficulty in legislative interpretation.

42 In terms of the Regulations Relating to Tissue Banks (GN R182 in GG 35099 of 2012-0302), a tissue bank is "an organisation, institution or person that provides or engages in one or more services including cells and/or tissue from living or deceased individuals for transplantation purposes and is registered in terms of regulation 3 of these regulations".

$43 \mathrm{~S} 60$ of the NHA.

4471 of 2008. A tissue bank could also be part of a tertiary institution, e.g., the Centre for Tissue Engineering at the Tshwane University of Technology.

$45 \mathrm{~S} 60(4)(b)$ of the NHA.

$46 \mathrm{~S} 60(5)$ of the $\mathrm{NHA}$.

$47 \mathrm{~S} 67(4)$ of the NHA. 


\section{Regulations}

\section{Regulations Regarding the General Control of Human Bodies, Tissue, Blood, Blood Products and Gametes $^{48}$}

The first regulation that is relevant in the Regulations Regarding the General Control of Human Bodies, Tissue, Blood, Blood Products and Gametes (General Control Regulations) concerning skin donations is regulation 8(1). This section stipulates that a retrieval officer has a period of 24 hours after the death of a person of whom tissue (skin) has been donated to remove the tissue so donated. As mentioned earlier, it is ideal to remove donated skin within 6 hours of death. Unfortunately, especially in cases of an unnatural death, it is not always possible to remove skin within the 24-hour period. Skin can sometimes be removed even 5 days after death. It takes approximately 30 to 45 minutes for a retrieval officer to retrieve skin with a battery-operated instrument. Skin is taken from the back of the legs, the thighs, the back of the arms and the back of the deceased. There are eight layers of skin, but only the uppermost layer is harvested. There is no bleeding, no mutilation takes place and there is no disfigurement. Bandages are placed over the parts where skin has been removed. The process described above is followed to uphold the dignity of the donor.

Regulation 9 addresses the establishment of death. Death according to the NHA is brain death. According to regulation 9, the death of a person should be established by at least two medical practitioners, one of whom shall have been practising as a medical practitioner for at least five years after the date on which he or she was registered as a medical practitioner. This is also relevant to the procurement of solid organs for transplantation. The regulation also indicates that in instances involving the removal of eye tissue, a person from whom the tissue is removed shall be deemed dead upon the issuing of a certificate of death in terms of the relevant law. Unlike with corneas, skin is not mentioned specifically in regulation 9. It is suggested that the regulations should be amended to include specific reference to skin, as skin can also be procured from a deceased who has been removed from a ventilator.

It appears that regulation 14(3) of the General Control Regulations should be read with section 62 of the NHA as it determines that if a person who has died has in their will or in a document donated tissue of their body, a medical practitioner may act upon a will or document that on the face of it appears to be legally valid. As indicated under the discussion of the NHA, despite this section, the practice in hospitals is always to ask the family for a donation and not to act on documents indicating the wish of the deceased. ${ }^{49}$

48 The Regulations Regarding the General Control of Human Bodies, Tissue, Blood, Blood Products and Gametes were published in the Government Gazette GN R180 in GG 35099 of 2012-03-02.

49 See Slabbert and Molusi "The Possible Effect of the Protection of Personal Information Act 4 of 2013 on Organ and Tissue Donations" 2017 Obiter 632-640. 


\section{Regulations Relating to Tissue Banks ${ }^{50}$}

The Regulations Relating to Tissue Banks (Tissue Bank Regulations) start by stipulating limitations on the use of human tissue. They state explicitly, among other things, that no one may remove, acquire, process or store human tissue (skin) unless he or she is authorised with the Department of Health. ${ }^{51}$ The Tissue Bank Regulations prescribe the procedure - namely, "an application for authorisation of a tissue bank shall be made to the Director General". ${ }^{2}$ Regulation 5 prescribes the organisational structure of a tissue bank. It may be freestanding (a non-profit company) or be part of an institution. ${ }^{53}$ All activities relating to tissue (skin) procurement and distribution for transplantation must comply with the Guiding Principles of the WHO and the Declaration of Istanbul. ${ }^{54}$ Every tissue bank should also have a medical director to advise and oversee the processes. ${ }^{55}$ Regulation $5(7)$ is problematic. It states that only a "competent person" may be involved with, among other things, the retrieval of tissue (skin) from cadavers. A "competent person" is defined in regulation 1 as "a medical practitioner and registered as such in terms of the Health Professions Act, 1974". Current practising tissue retrieval officers are not registered medical practitioners as required by the Regulations. Therefore, it is submitted that the drafters of the Regulations have made an error in this regard as it is not common practice, nor is it necessary, to have the competencies of a medical practitioner to successfully procure human tissue (skin) for transplantation purposes.

Regulation 6 prescribes the record management systems a tissue bank needs to maintain. The whole donation process from the donor to the ultimate recipient of the skin should be easily traceable. The following documentation should be available at the tissue bank: the consent form, the donor suitability assessment, an explanation of the retrieval processes, the quarantine and infectious disease testing documents and reports, as well as the processes done in the laboratories to preserve the donated tissue (skin), and the final labelling, storage and distribution records. ${ }^{56}$ There must also be a system in place to notify the Director General about serious adverse events that may influence the safety and quality of the skin. ${ }^{57}$ Regulation 6(5) determines that all information at a tissue bank pertaining to donors and recipients is confidential. ${ }^{58}$ Regulation 8 prescribes that a tissue bank shall be inspected every year for compliance. Unfortunately, this is not always

\footnotetext{
GN R182 in GG 35099 of 2012-03-02.

Reg 2(1) of the Tissue Bank Regulations.

Reg 3(1) of the Tissue Bank Regulations.

The Centre for Tissue Engineering is a part of the Tshwane University of Technology (SA).

54 Reg 5(2) of the Tissue Bank Regulations. See also the website of the WHO at www.who.org and the Declaration of Istanbul at www.declarationofistanbul.org. South Africa is a signatory of the Declaration and a member state of the WHO and is therefore bound by the prescriptions of both concerning organ and tissue donations.

55 Reg 5(4) of the Tissue Bank Regulations.

56 Reg 6(1) of the Tissue Bank Regulations. See also reg 14.

57 Reg 6(1)(d) and (e) of the Tissue Bank Regulations.

58 See also reg 15 of the Tissue Bank Regulations. See also Slabbert and Molusi 2017 Obiter 632-640.
} 
complied with by the Department of Health. Regulation 21 makes it an offence to contravene or fail to comply with any provision of the Regulations. A person found guilty is liable to a fine not exceeding R40000 and/or imprisonment for a period not exceeding two years.

If the Tissue Bank Regulations are applied to skin donations, the following is clear. Only a retrieval officer from an authorised tissue bank may remove skin from a deceased's body. The officer must then transport the donated skin to the tissue bank. After skin has been procured from a cadaver, blood tests and other medical tests are done to determine whether there are any infectious agents present that may cause transplantation-transmitted diseases. Cadavers excluded from skin donation include where HIV, hepatitis $B$ and $C$, sexually transmitted infections, active skin cancers or septicaemia is present. 59 If the potential donor does not have the above conditions, the procured skin is preserved, stored, labelled and packed according to approved standard operating procedures. ${ }^{60}$ Skin is preserved in an 85 per cent glycerol solution and is stored at between 4 and 8 degrees Celsius. The skin is then distributed in specified holders for transplantation to burn units.

In this part of the article under heading 2, the NHA and its various regulations (insofar as both relate to skin donations) have been discussed and certain shortcomings have been indicated. In general, there is enough guidance to regulate the donation of skin even though not always ideal and sometimes ambiguous. In the following section, the legal and regulatory environment relating to skin donations in the United Kingdom (England and Wales) is briefly discussed. By providing a brief overview of how skin donation, transplantation and banking is regulated in the UK, the following section aims to determine whether any improvements should be made to the South African framework.

\section{THE LAW AND SKIN DONATIONS IN THE UNITED KINGDOM}

The importance of tissue donation can often seem trivial when compared to organ donation. Historically, the latter has gained more attention from politicians, legislators, clinicians and the general public, even though tissue donation and banking were the forerunner in this environment. The first tissue bank in the United Kingdom (UK) was established in Leeds in 1956.61 In less than a decade, by 1965, it had outgrown its facility and the Yorkshire Regional Tissue Bank was established to provide skin, bone and heart valves. ${ }^{62}$ This was later followed by the establishment of a further two tissue

59 See Skin Donation "Facts" (undated) http://www.skindonation.in/facts.html (accessed 201902-06).

60 Compliant with ISO 31000:2009 (revised by ISO 31000:2018), which provides principles and generic guidelines on risk management.

61 Phillips and Pedraza "The Use of the Ionization Technique for Tissue Sterilization: The International Atomic Energy Agency (IAEA) Experience" 2013 Cell Tissue Bank 341-348.

62 Guam, Reynolds, Jones, Clarkson, Gillan and Kaye "Tissue and Corneal Donation and Transplantation in the UK" 2012 British Journal of Anaesthesia i43-47, i43. 
banks in London and Cambridge. ${ }^{63}$ Eventually a decision was made by the National Blood Service ${ }^{64}$ to centralise tissue banking services (apart from eye banking) throughout the UK, and in 2005 a multi-tissue bank was established in Liverpool, which currently provides a national comprehensive tissue service to the National Health Service (NHS). ${ }^{65}$ Even though, the Liverpool centre coordinates most donations of deceased tissue, it is not the sole supplier, as other private and public establishments are also involved in the supply of tissue. ${ }^{66}$

From a clinical point of view, great strides were being made to establish and develop tissue donation and banking. However, this was not the case in the legislative and regulatory environment. The process of tissue donation was, fortunately, prescribed by the Human Tissue Act 1961 (which also governed the organ donation process) but, up until 1993, there was no guidance pertaining to the regulation of tissue banks. ${ }^{67}$ In other words, there was no consensus on how to approach donor selection, retrieval, storage, distribution or tracking of allografts. ${ }^{68}$ Consequently, the American Association of Tissue Bank's guidelines were followed until the British Association of Tissue Banking developed the first set of UK tissue banking standards. ${ }^{69}$

Today, tissue donation, transplantation and banking are regulated by a vast collection of legislative and regulatory sources. These are discussed below. It should be noted that this section only focuses on the framework followed in England and Wales. ${ }^{70}$

\section{Overview of the legal and regulatory framework}

Tissue donation is often described as life-enhancing as opposed to lifesaving. Even so, its significance is clearly reflected in the fact that 7453 tissue products were issued during 2019/2020.71 The donation,

63 NHS Blood and Transplant "History of Tissue Banking" https://www.nhsbt.nhs.uk/tissueand-eye-services/about-us/history-of-tissue-banking/ (accessed 2020-12-16).

64 Currently, the National Blood Service forms a part of the NHS Blood and Transplant (NHSBT).

65 NHSBT https://www.nhsbt.nhs.uk/tissue-and-eye-services/about-us/history-of-tissuebanking/ (accessed 2020-12-16).

66 Nuffield Council on Bioethics "Human Bodies: Donation for Medicine and Research" (2011) https://www.nuffieldbioethics.org/publications/human-bodies-donation-for-medicine-andresearch (accessed 2020-12-16).

67 NHS Blood and Transplant "Regulatory Compliance" https://www.nhsbt.nhs.uk/tissue-andeye-services/safety-and-quality/regulatory-compliance/ (accessed 2020-12-17).

68 Freelander, Boyce, Ghosh, Ralston and MacNeil "Skin Banking in the UK: The Need for Proper Organisation" 1998 Burns 19-24 19.

69 Ibid.

70 The legislative and regulatory framework regarding organ and tissue donation and transplantation is a devolved issue within the UK.

71 NHSBT Annual Report and Accounts 2019/2020 https://assets.publishing.service.gov.uk/ government/uploads/system/uploads/attachment_data/file/924960/30204_022nd_Annual_R eport_and_Accounts_2019-2020_Accessible.pdf (accessed 2020-12-12). The statistics are based on skin, heart valves and tendons. Unfortunately, statistics that focus solely on skin products were not available. 
transplantation and banking of tissue is governed by a broad array of legal sources, including primary and secondary legislation, common law as well as guidance provided by statutory and non-statutory bodies. The discussion that follows distinguishes between the sources regulating 1) the donation and transplantation of tissue, and 2) tissue establishments.

\section{The donation and transplantation of tissue}

The term "consent" has become inseparable from the practice of organ and tissue donation, in that the Human Tissue Act 2004 (HT Act) regards it as the fundamental principle that underpins the lawful storage, use and removal of human tissue. The HT Act specifically refers to securing "appropriate consent". When the Act is read alongside the Organ Donation (Deemed Consent) Act 2019 (in England) and the Human Transplantation (Wales) Act 2013 (in Wales), "appropriate consent" is to be understood as "deemed consent" in certain circumstances. ${ }^{72}$ In other words, if an individual is over 18 , he or she will be considered as a potential organ and tissue donor after death, unless he or she makes a decision not to be a donor or has nominated a representative to make a decision on his or her behalf. ${ }^{73}$ Neither the HT Act nor the Acts relating to the deemed consent system mandate how an individual should record a decision regarding tissue donation. ${ }^{74}$ Thus, a potential donor can record their wish on the Organ Donor Registry, tell a friend or family member (nominated representative) or record their decision in writing. In essence, the information should lead a reasonable person to conclude that the potential donor would have consented to the donation. ${ }^{75}$ The consent process above relates to the potential donor whereas the consent process followed by the health care professionals within the clinical context is further discussed below under heading 3.2. It is important also to highlight in this section that the Human Tissue (Permitted Material: Exceptions) (England) Regulations 2020 stipulate that certain tissue may only be procured if expressed consent (as opposed to deemed consent) was obtained. ${ }^{76}$ Skin is not regarded as an excluded material, but it is worth noting that express consent is required for skin donation that forms part of a novel or rare transplant - for example, with skin that forms part of the face. ${ }^{77}$ The HT Act makes provision for a number of offences, but most relevant to this discussion is that it is an offence to

72 Apart from the primary legislation above, other legal instruments should also be consulted when dealing with skin donation and transplantation. These include, but are not limited to, the Mental Capacity Act 2005, Human Rights Act 1998 and Equality Act 2010, as well as the relevant Human Tissue Authority Codes of Practice.

73 S 3 of the HT Act; s 1 of the Organ Donation (Deemed Consent) Act 2019; s 4 of the Human Transplantation (Wales) Act 2013. (Note, the Welsh legislation makes use of the term "express consent".)

74 Human Tissue Authority Code F: Donation of Solid Organs and Tissue for Transplantation (Part Two: Deceased Organ and Tissue Donation) (2020) 54.

75 HTA Code F (Part Two) 48.

76 Reg 2 of the Human Tissue (Permitted Material: Exceptions) (England) Regulations 2020.

77 See reg 2(a)-(x) of the Human Tissue (Permitted Material: Exceptions) (England) Regulations 2020 for the complete list of excluded materials. 
remove tissue without consent, ${ }^{78}$ and to store or use tissue for anything other than a qualifying purpose..$^{79}$

Under the HT Act, the Human Tissue Authority (HTA) was established to act as the regulator for human tissue and organs. ${ }^{80}$ The HTA's role as a statutory body is to provide codes of practice and standards that prescribe both procurement and transplantation activities. ${ }^{81}$ These codes aim to provide guidance to health professionals carrying out transplant activities. ${ }^{82}$ In other words, the codes serve as an extremely helpful resource that all individuals involved with donation and transplantation activities can consult for assistance in navigating more easily the legislative and regulatory framework. Additionally, the HTA's active role is to ensure that all tissue establishments comply with the necessary quality and safety standards. This role is discussed below.

\section{Tissue establishments}

Unlike in the early 1990s, the tissue banking process is now governed by legislation. The European Tissues and Cells Directive, consisting of the European Union (EU) Directive on Tissues and Cells ${ }^{83}$ and its associated Commission Directives ${ }^{84}$ were transposed into UK law by means of the Human Tissue (Quality and Safety for Human Application) Regulations 2007. It should be noted that these regulations, following Brexit, have been amended and should be read alongside the Human Tissue (Quality and Safety for Human Application) (Amendment) (EU Exit) Regulations 2019/481 and the Human Tissue (Quality and Safety for Human Application) (Amendment) (EU Exit) Regulations 2020. The EU Exit Regulations were drafted to ensure that, upon leaving the EU, the UK would maintain current safety and quality standards for blood, organs, tissue and cells. ${ }^{85}$

In addition to the HT Act's relevant sections on consent discussed above, these regulations set out to regulate activities concerning the intended use of human tissue and cells in or on a human recipient. ${ }^{86}$ The purpose of these regulations is to ensure high standards of quality and safety when transplanting human tissue, as well as to establish a unified approach to tissue banking throughout the European Community. ${ }^{87}$ The frameworks above are applicable to "tissue establishments", which includes tissue banks

\footnotetext{
$S 5$ of the HT Act.

$\mathrm{S} 8$ of the HT Act.

$\mathrm{S} 13$ of the HT Act.

See HTA Codes of Practice https://www.hta.gov.uk/guidance-professionals/codes-practice (accessed on 2021-01-16): Code A: Guiding Principles and the Fundamental Principles of Consent (2020); Code F (Part Two).

82 HTA Code $F$ (Part Two) 43.

83 Directive 2004/23/EC of the European Parliament and of the Council (31 March 2004).

84 Commission Directives 2006/17/EC (8 February 2006) and 2006/86/EC (24 October 2006).

85 Human Tissue (Quality and Safety for Human Application) (Amendment) EU Exit Regulations 2020 Explanatory Notes.

86 Human Tissue (Quality and Safety for Human Application) Regulations 2007 Explanatory Notes.
}

87 Ibid. 
as well as other units that store skin for autografts. Typically, these are burns and plastic surgery units within a hospital. In accordance with the Regulations, skin is regarded as tissue as "tissue" includes "all constituent parts of the human body formed by cells, but does not include (a) gametes, (b) embryos outside of the human body, or (c) organs or parts of organs if it is their function to be used for the same purpose as the entire organ in the human body". ${ }^{88}$

As seen above, the HTA also has a part to play in this process. In accordance with the Regulations, its role as "designated competent authority" is to license the establishments that procure, process, store, distribute, import or export tissues for human application.89 The HT Act empowers the HTA to issue all tissue establishments with the necessary directions $^{90}$ and codes of practice ${ }^{91}$ to ensure that the establishments are complying with the expected standards. Additionally, the HTA has the power to inspect or search the tissue establishments. ${ }^{92}$

Due to the limited scope of this article, only the key regulations and their relevance to tissue establishments are briefly noted. In the first instance, an appropriate HTA licence is required by any establishment that stores or imports skin for human application. ${ }^{93}$ An establishment that holds an HTA licence may then enter into a third party agreement with another establishment, which will then be allowed to procure, test, process, export or distribute skin on their behalf. ${ }^{94}$ In order to obtain a licence, an establishment is required to comply with requirements relating to i) staff and facilities; ii) quality management procedures; iii) reporting; and iv) records. ${ }^{95}$ Notably, the main point of interest under the licensing agreement is the requirement to appoint a "designated individual" (DI) who plays a key role in ensuring that the quality and safety requirements of the Regulations are implemented. ${ }^{96}$ The $\mathrm{DI}$ must hold the required qualifications as prescribed by the Regulations,,$^{97}$ and fulfil the statutory duties as set out by regulation 12 . These duties include that the DI should ensure that suitable practices are used when undertaking licensed activities; that others working under the licence are suitable and that all other conditions of the licence are complied

\footnotetext{
Reg 5 of the Human Tissue (Quality and Safety for Human Application) Regulations.

Reg 3 of the Human Tissue (Quality and Safety for Human Application) Regulations.

90 See HTA Guide to Quality and Safety Assurance for Human Tissues and Cells for Patient Treatment (2021) http://docplayer.net/11257872-Human-tissue-authority-guide-to-qualityand-safety-assurance-for-human-tissues/ (accessed on 2021-01-15).

91 See HTA Code $A$ and HTA Code F (Part Two).

92 Part 5 of the Human Tissue (Quality and Safety for Human Application) Regulations.

93 Reg 7(1) of the Human Tissue (Quality and Safety for Human Application) Regulations.

94 Reg 6 of the Human Tissue (Quality and Safety for Human Application) Regulations.

95 Reg 11 of the Human Tissue (Quality and Safety for Human Application) Regulations.

96 Ibid.

97 Reg 11(3) of the Human Tissue (Quality and Safety for Human Application) Regulations. The DI is required to be a suitable person to fulfil their statutory duties and furthermore must have either a diploma, certificate or other formal qualification in the field of medical or biological sciences or be suitably qualified based on academic qualification and practical experience.
} 
with, such as the requirements relating to information and confidentiality..$^{98}$ An additional noteworthy focal point of the Regulations is the requirement relating to the register and the reporting obligations that are placed both on the HTA and the tissue establishments. According to regulation 19, all serious adverse events and reactions affecting donors or recipients in human application treatment must be reported to the HTA. ${ }^{99}$ This information alongside a register of the licensed establishments and the activities they are allowed to carry out must be publicly accessible. ${ }^{100}$ Lastly, as it relates to the discussion under heading 5 below, a brief mention should be made to the fact that the Regulations (read in conjunction with the HTA directions) ${ }^{101}$ allow for the import and export of tissue and cells. ${ }^{102}$

\section{Tissue donation pathway}

Given that the effectiveness of tissue donation and transplantation laws relies largely on how they operate and are implemented within the clinical environment, it is necessary also to provide an outline of the clinical pathway of tissue donation in England and Wales. As most of the technicalities involved in the tissue donation and transplantation process are discussed elsewhere in this article, this section briefly explains only the five main stages followed.

Before the process is outlined, it should be noted that specialist nurses $(\mathrm{SN})^{103}$ play a key role in the tissue donation pathway. ${ }^{104}$ The process below focuses solely on tissue donation. However, it should be noted that during the organ donation process, consent can also be requested simultaneously to procure tissue. The process is initiated by the identification and referral of the potential donor. ${ }^{105}$ This action is usually triggered by the clinical staff at a relevant hospital, after they have spoken to the family about the option of tissue donation and explained that a referral will be made. The referral will most likely be made to the National Referral Centre (NRC) in Liverpool and should be made as soon as possible after verification of death. Interestingly, in 2020, the Gloucestershire Hospitals NHS Foundation Trust decided to pioneer a tissue donation initiative in England where two $\mathrm{SN}$ in tissue donation were appointed within the hospitals to streamline the donation

98 Reg 12 and 13 of the Human Tissue (Quality and Safety for Human Application) Regulations.

99 Reg 19(1) of the Human Tissue (Quality and Safety for Human Application) Regulations.

100 Reg 18 and 19(2) of the Human Tissue (Quality and Safety for Human Application) Regulations.

101 HTA Guide to Quality and Safety Assurance for Human Tissues and Cells for Patient Treatment https://www.hta.gov.uk/sites/default/files/HTA\%20Guide\%20to\%20Quality\%20 and\%20Safety\%20Assurance\%20for\%20Human\%20Tissues\%20and\%20Cells\%20for\%20 Patients\%20Treatment_1.pdf.

102 Reg 15 of the Human Tissue (Quality and Safety for Human Application) Regulations.

103 For purposes of this article a SN includes a specialist nurse involved in organ donation (SNOD), a specialist nurse involved in tissue donation (SNTD) and a specialist requester.

104 HTA Code F (Part Two) 47.

105 Guam et al British Journal of Anaesthesia i43-47, i44. 
pathway. ${ }^{106}$ Ordinarily, the team of $\mathrm{SN}$ at the NRC receive the donor referral and subsequently contact the potential donor family to discuss donation options. ${ }^{107}$ The SN complete the consent and donor screening process in accordance with the legislative and regulatory framework discussed above. ${ }^{108}$ The next stage is to retrieve the tissue. The retrieval takes place in a mortuary in liaison with the NRC and the mortuary team. ${ }^{109}$ The potential donor should usually be in the mortuary within six hours of confirmation of circulatory death for optimal tissue retrieval. ${ }^{110}$ In essence, the donor is prepared as if they were undergoing a surgical procedure and is also reconstructed afterwards to an appearance that is reflective of their predonation state. ${ }^{111}$ By following this approach, the donor is treated in a way that upholds and respects their dignity. ${ }^{112}$ After procuring the skin, it is transported to the tissue bank, where it is processed immediately to conserve the structure of the tissue. ${ }^{113}$ The final stage of the process is to use the skin for transplantation purposes. Here, the skin product is most often ordered from the NRC via hospitals across the UK, and is ultimately transplanted to the recipient. ${ }^{114}$

After careful consideration of the legislative and regulatory framework, as well as the clinical pathway regarding tissue donation in England and Wales, this article concludes that the South African legislature could draw two initiatives from the UK's approach to tissue donation, transplantation and banking. First, South Africa could benefit from establishing a regulatory body like the HTA. This body would not only improve the acute tissue shortage in the country but might also have a positive impact on both deceased and living organ donation rates. Secondly, and related to the first initiative, is the drafting and subsequent dissemination of professional guidance regarding tissue donation and transplantation. The professional guidance would assist those working in the field to navigate the ambiguous NHA and its accompanying regulations. In addition, accessible professional guidance would ensure a consistent approach by all individuals practising in this area. It is, however, acknowledged that the South African environment faces certain hinderances since donation and transplantation services are not centralised by a single body (like the NHS) rooted within a public health care

106 NHS Gloucestershire Hospital Foundation Trust "Gloucestershire Hospitals Pioneer New Organ Donation Approach" https://www.gloshospitals.nhs.uk/about-us/news-media/pressreleases-statements/gloucestershire-hospitals-pioneer-new-organ-donation-approach/ (accessed 2021-01-18).

107 NHSBT "Tissue and Eye Services" https://www.nhsbt.nhs.uk/tissue-and-eye-services/aboutus/ (accessed 2021-01-18)

108 Ibid.

109 Guam et al 2012 British Journal of Anaesthesia i43-47, i45.

110 Joint United Kingdom Blood Transfusion and Tissue Transplantation Services Professional Advisory Committee "Guidelines for the Blood Transfusion Services in the United Kingdom" (2013) https://www.transfusionguidelines.org/red-book/ (accessed 2021-01-18).

111 Guam et al 2012 British Journal of Anaesthesia i43-47, i45.

112 NHSBT "Get the Facts About Organ Donation" https://www.organdonation.nhs.uk/helping you-to-decide/about-organ-donation/get-the-facts/ (accessed 2021-01-18).

113 Guam et al 2012 British Journal of Anaesthesia 108 (S1) i43-47, i45.

114 Clinton "Staring Down Death to Save Lives: The Grisly Work of Human Tissue Banks" (2014) https://www.express.co.uk/life-style/health/505460/Life-inside-the-Liverpool-NHS human-tissue-bank (accessed 2021-01-17). 
sector. Thus, it should be borne in mind that any improvements to the South African framework should take cognisance of the private/public health care sector divide.

Apart from legislative and regulatory shortcomings, there are also other factors that influence the availability of skin. The following section analyses the possible reasons for the shortage of donated skin in South Africa.

\section{POSSIBLE REASONS FOR DONATED SKIN SHORTAGES}

\section{The will of the deceased or the family}

As discussed above, family members can veto a decision that the deceased expressed while still alive. ${ }^{115}$ If the next of kin being asked for a donation are not aware of the deceased's wishes, they usually do not consent to the donation. If they know that the deceased wanted to donate, the decision to consent is simplified as it is then based on the family members' motivation to fulfil the wishes of the deceased. More public awareness regarding donations is thus essential. ${ }^{116}$ Some authors like Emson have different views and are of the opinion that the right of control over the cadaver should be vested in the State as representative of those who may benefit from a donation. ${ }^{117}$ Among other arguments, he reasons that the cadaver has changed from an object without intrinsic value destined only for disposal, and has now become a vital resource. ${ }^{118} \mathrm{He}$ argues the following:

"The concept of the right of a person to determine before death, the disposal of their body after death, made sense only when there was no continuing use for that body; it makes neither practical nor moral sense now, when the body for which the dead person no longer has any use, is quite literally a vital resource, a potential source of life for others ... If this argument is correct, then it is even more morally unacceptable for the relatives of the deceased to deny utilisation of the cadaver as a source of transplantable organs [tissue] ... The need of the potential recipient, the benefit which may accrue to him or her, to me trumps and surpasses all other considerations." 119

His argument is based on the fact that "opting in", where people voluntarily donate their organs, has failed and he therefore feels strongly that the relatives should not have a right over the deceased. He further argues that to ask for their consent to procure organs or tissue from the deceased is

115 See Beauchamp and Childress 2009 Principles of Biomedical Ethics 359: "In practice ... few individuals sign donor cards, the cards are rarely available at the time of death, and procurement teams routinely seek authorization from the family, even if the decedent left a valid donor card. The family has become the primary donor (i.e., the decision maker about donation) rather than the individual."

116 See also Slabbert and Venter "Autonomy in Organ Donations v Family Consent: A South African Legislative Context" 2019 De Jure Law Journal 458-467.

117 Emson "It Is Immoral to Require Consent for Cadaver Organ Donation" $2003 \mathrm{~J} \mathrm{Med} \mathrm{Ethics}$ 125-127.

118 Emson 2003 J Med Ethics 126

119 Ibid. 
unacceptable, as the good of others (the recipients) should be the predominant concern. ${ }^{120}$

Harris echoes these views when he says:

"The benefits from cadaver transplants are so great, and the harm done in going against the wishes of those who object so comparatively small, that we should remove altogether the habit of seeking the consent of either the deceased or relatives [and therefore] provide for the automatic or mandatory availability of donor organs [tissue]."

\section{Not enough donors}

The NHA and its regulations have been discussed above. South Africa follows a procurement system called "opting in". This means a tissue (skin) donor must indicate while he or she is still alive an intention to donate skin after death. If there is no indication that is what the deceased wanted, the family will be asked for consent, as explained above. In other words, the donations are altruistic, and consent needs to be given, either by the deceased him- or herself, while living, or the next of kin after death. Other countries such as the UK (England and Wales), France, Spain and Belgium follow a system of "opting out". In such a system, every citizen is an organ or tissue donor unless the individual records in writing his or her objection to a donation before death. To change to such a system in South Africa might not be viable as "[t]he poor and uneducated may be disadvantaged as only the more informed groups would exercise autonomy, since only they would be aware of their right to opt-out". ${ }^{122}$ An opt-out system also creates a reverse burden of proof that might not withstand constitutional muster. ${ }^{123}$ Spain, a country that has seen a continuous increase in deceased donors for over 20 years has had a system of opting out since 1979 but despite having this system, relatives are still always asked for consent before a donation takes place. It thus seems that it is not the system of opting out that has increased the number of donors in Spain; it is rather having an organisational approach that strongly relies on routine referrals for the process of deceased donations. ${ }^{124}$ Noyes et al came to a similar conclusion in their short-term impact study of introducing a soft opt-out organ donation system in Wales. ${ }^{125}$ Their study concluded that the change to an opt-out system did not

120 Emson 2003 J Med Ethics 127. See also Savulescu "Death, Us and Our Bodies: Personal Reflections" 2003 J Med Ethics 127-130; Harris "Organ Procurement: Dead Interests, Living Needs" 2003 J Med Ethics 130-139.

121 Harris $2003 \mathrm{~J}$ Med Ethics 130.

122 Taylor Stakes and Kidneys: Why Markets in Human Body Parts Are Morally Imperative (2005) 8. See also Etheredge, Penn and Watermeyer "Opt-In or Opt-Out to Increase Organ Donation in South Africa? Appraising Proposed Strategies Using an Empirical Ethics Analysis" 2018 Developing World Bioethics 119-125.

123 See Slabbert "This Is My Kidney, I Should Be Able to Do With It What I Want: Towards A Legal Framework for Organ Transplants in South Africa" 2012 (31) Medicine and Law 617-640.

124 See Slabbert and Venter "Routine Referrals: A Possible Solution for Transplantation Shortages" 2017 SAJBL 15-19.

125 Noyes, McLaughlin, Morgan, Walton, Curtis, Madden, Roberts and Stephens "Short-Term Impact of Introducing a Soft Opt-Out Organ Donation System in Wales: Before and After Study" 20199 British Medical Journal doi:10.1136/ bmjopen-2018-025159. 
necessarily have an immediate impact on the organ donation rates but that it should rather be regarded as "the first step of a longer journey". ${ }^{126}$ It is worthwhile to note here that Kent is of the opinion that a lack of potential donors might not be the sole factor contributing to the shortage of donor tissue but that health professionals' attitudes and lack of awareness also has an impact. ${ }^{127}$

\section{No procurement agency}

South Africa's legislation on donations is, as indicated above, only a chapter within an Act. ${ }^{128}$ Although the regulations were drafted with the aim of expanding on the Act, there is in certain instances a lack of clarity, as highlighted above. Most other countries where tissue donations take place have separate specific pieces of legislation addressing only donations and transplantation. In some instances, these distinct legislative frameworks create procurement organisations to assist with the procurement of donated organs or tissue. In the United States of America, the National Organ Transplant Act of 1984 created the United Network for Organ Sharing (UNOS) ${ }^{129}$ and the Organ Procurement and Transplant Network (OPTN). ${ }^{130}$ Both these organisations are involved in the procurement and distribution of donated organs or tissue. In the UK, the HT Act 2004, created the HTA, which acts as the regulator for human tissue and organs. ${ }^{131}$ As a statutory body, and as discussed above, the HTA provides codes of practice and standards that prescribe both procurement and transplantation activities to which all licensed hospitals are required to adhere. ${ }^{132}$ Unlike UNOS, the HTA is not directly involved with the allocation of tissue and organs. This role is fulfilled by the National Health Service Blood and Transplant (NHSBT), a special health authority tasked with ensuring that a fair, transparent and equitable approach to patient selection and organ allocation is followed. ${ }^{133}$ Spain has a National Transplant Organisation (NTO) as part of Spain's health ministry. ${ }^{134}$ South Africa does not have a procurement agency, nor is the process of donation or transplantation nationally controlled. There is not even a national waiting list for patients in need of an organ or tissue. There is also not a national list of organ or tissue donors except for the list of registrations that is maintained and held by the ODF. This registry comprises only the names of people who have indicated their willingness to be an organ or tissue donor after death, but it has no legally binding powers.

126 Ibid.

127 Kent "Tissue Donation and the Attitudes of Health Care Professionals" in Organ and Tissue Donation: An Evidence Base for Practice (2007) 102-122, 103.

128 Ch 8 of the NHA.

129 United Network for Organ Sharing (UNOS) https://unos.org.

130 Organ Procurement and Transplant Network (OPTN) https://optn.transplant.hrsa.gov.

131 Human Tissue Authority (HTA) www.hta.gov.uk.

$132 \mathrm{~S} 13$ of the HT Act.

133 NHSBT "Introduction to Patient Selection and Organ Allocation Policies" POL 200/4.1/2017.

134 Deutsches Referenzzentrum für Ethik in den Biowissenschaften "The Spanish Transplantation System" http:/www.drze.de/in-focus/organ-transplantation/modules/dasspanische-transplantationswesen. 


\section{Lack of education (fear of mutilation)}

Tissue donations generally occur less often than solid organ donations. A possible reason might be a lack of public understanding regarding the difference between organ and tissue donation. Some people think that if they sign an organ donor card it does not include the use of tissue after death. ${ }^{135}$ Siminoff et al also indicate that the process around tissue donations differs from the donation of solid organs. The donation of solid organs is time sensitive and therefore a transplant coordinator would approach the family of a brain-dead patient in person to ask for a donation. Tissue can be procured after death in a mortuary or at a funeral parlour and therefore the family could be asked telephonically for a donation. This has been a problem for some families as they do not understand the process of tissue procurement after their deceased loved one has been moved from the hospital. Some are even suspicious that tissue could easily be sold for commercial gain whereas organs can only be used for transplantation in a patient who needs an organ and the process takes place in hospital. ${ }^{136}$

Sque et al report that family members have declined tissue donations because of a fear of the body being disfigured. ${ }^{137}$ Family members also feel the deceased has suffered enough and that they (the family) must protect the dead body and must not relinquish their guardianship of the body. ${ }^{138}$ The aim of Sque et als research was specifically to find out why families declined a donation after death, but apart from the obvious comments made by the family members, they discovered there were underlying issues such as a perceived violation of a body, a perceived desecration of the dead body, a feeling that the perfect aesthetic image of the deceased would be destroyed and a perceived view that the deceased would be exposed to prolonged suffering as it was impossible for family members to detach themselves from the person they once loved and admired. ${ }^{139}$

Although no formal studies on why people do not want to donate skin after death in South Africa has been done, it could be accepted that families would have the same issues as highlighted above. This once again shows a lack of awareness and knowledge on skin donations. Tissue banks should therefore focus more on campaigns to inform the public how skin donations are done and emphasise that the body will not be mutilated - an open casket funeral is still possible as the skin is taken from the back or the legs and arms of the deceased and only the top layer is removed; the body is thus not skinless or mutilated.

It is clear that there is not yet enough information on tissue donations in South Africa. This could be seen as a contributing factor to the overarching problem with donation shortages. People are asked for a donation at a very

135 Siminoff, Traino and Gordon "Determinants of Family Consent to Tissue Donation" 2010 69(4) J Trauma 956-963.

136 Siminoff et al $2010 \mathrm{~J}$ Trauma 963.

137 Sque, Long, Payne and Allordyce "Why Relatives Do Not Donate Organs for Transplants: 'Sacrifice' or 'Gift of Life'?” 2007 61(2) Journal of Advanced Nursing 134-144.

138 Sque et al 2007 Journal of Advanced Nursing 138.

139 Sque et al 2007 Journal of Advanced Nursing 140. 
vulnerable time. They are grieving the loss of a family member. This combined with ignorance concerning skin donations or how skin is procured from a dead body is a recipe for failure. South Africa desperately needs skin for all the burn victims but unless there is better education of the population at large, there will always remain a shortage of donated skin despite the high level of deaths in South African hospitals. The possibility of importing skin should thus also be investigated.

\section{IMPORTATION OF CADAVER SKIN}

Section $68(1)(g)$ of the NHA gives authority to the Minister to make regulations regarding the importation of tissue. In March 2012, this was done through the promulgation of the Regulations Relating to the Import and Export of Human Tissue, Blood, Blood Products, Cultured Cells, Stem Cells, Embryos, Foetal Tissue, Zygotes and Gametes (Import Regulations). ${ }^{140}$ According to regulation 2, no person may import tissue without a permit. A person who wishes to import tissue (skin) must apply in writing to the Director-General (DG) on a prescribed form attached to the regulations. Once the application is received, the DG issues a permit to the person authorising him or her to import tissue (skin), subject to conditions as the DG may determine and record on the permit. In the case of tissue for therapeutic use (for example, skin for burn wounds), an import permit may only be issued if the application is accompanied by information in respect of the health status of the donor, particularly regarding transmissible diseases and the results of tests performed in that regard. ${ }^{141}$ The DG may refuse to issue an import permit if the relevant information has not been provided. In such a case, the DG must give reasons in writing for the refusal. ${ }^{142}$ The person who applied for the import permit must keep record of each importation and such record must be submitted to the DG before the end of February each year, for the preceding calendar year. ${ }^{143}$ Each consignment of tissue (skin) imported into the Republic must be accompanied by a certificate from the supplier, stating that the biological substance (skin) has been exported in terms of applicable laws and regulations of the country from which the substance originates. ${ }^{144}$

A register must be kept by an authorised institution (tissue bank) that has imported skin in terms of the Regulations. ${ }^{145} \mathrm{~A}$ copy of the register must be provided to the DG at intervals not exceeding six months and the register itself must be kept for a minimum period of five years after the last entry in such register. ${ }^{146}$

It thus seems possible for a registered tissue bank to import skin, should it be regarded as a viable option for the skin shortages locally.

140 Reg R181 of GG 35099 of 2012-03-02.

141 Reg 4(3) of the Import Regulations.

142 Reg 4(5) of the Import Regulations.

143 Reg 4(8) of the Import Regulations.

144 Reg 4(10)(b) of the Import Regulations.

145 Reg 7 of the Import Regulations.

146 Reg 7(3) of the Import Regulations. 


\section{$6 \quad$ CONCLUSION}

In general, skin and organ or tissue donations do not affect people daily and therefore few really care about it, or so it seems. However, if a family member is in dire need of a kidney or a liver to save their life, or a child has been severely burned, suddenly relatives and friends become aware of organ or tissue donations. This should change. There should be more awareness campaigns on the need for skin specifically. Information should highlight that nearly every deceased person can donate skin without the body being mutilated. This will give hope to the many burn victims suffering from indescribable pain and suffering.

The article started with a quote, and we would like to end with a quote from an unknown author in the same book as at the beginning:

"Don't think of organ [skin] donation as giving up part of yourself to keep a total stranger alive. It's really a total stranger giving up almost all of themselves to keep part of you alive."147

147 Mezrich How Death Becomes Life 269. 